\title{
RODNE RAZLIKE U PERCEPCIJI ODNOSA SA SESTROM I MANIFESTACIJI PROAKTIVNE I REAKTIVNE AGRESIVNOSTI KOD MLADIH ADOLESCENATA
}

\author{
SAŽETAK
}

Glavni cilj provedenog istraživanja bio je ispitati ulogu kvalitete odnosa među braćom i sestrama u objašnjenju agresivnog ponašanja u adolescenciji. Odnosno, ispitao se doprinos pojedinih dimenzija kvalitete odnosa (toplina, konflikti i majčino favoriziranje) sa sestrom u objašnjenju zastupljenosti proaktivne i reaktivne agresivnosti mlađih adolescenata. $U$ istraživanju su sudjelovali dječaci $(N=160)$ i djevojčice $(N=192)$ u dobi od 13 do 15 godina koji su imali do 5 godina stariju ili mlađu sestru. Rezultati analiza rodnih razlika ukazuju da su dječaci skloniji iskazivanju proaktivne i reaktivne agresivnosti te da u usporedbi s dječacima, djevojčice percipiraju značajno više topline u odnosu sa sestrom.

Izvorni znanstveni članak

Primljeno: Ožujak, 2015.

Prihvaćeno: Lipanj, 2015.

UDK: $159.922 .8-055.2$

D0I: $10.3935 /$ ljsr.v22i2.65

Marina Jurkin ${ }^{1}$

Jelena Ombla²

Sveučilište u Zadru

Odjel za psihologiju

Ključne riječi:

kvaliteta odnosa sa sestrom, proaktivna i reaktivna agresivnost, rana adolescencija. 
Provedene korelacijske i regresijske analize potvrđuju pretpostavke o značajnoj povezanosti pozitivnih i negativnih aspekata odnosa sa sestrom s nekim aspektima psihosocijalnog funkcioniranja u mješovitim (brat-sestra) $i$ istorodnim dijadama (sestra-sestra). Konkretnije, dimenzija konflikata u odnosu sa sestrom izdvojila se kao značajan nezavisan prediktor reaktivne i proaktivne agresivnosti $i$ kod dječaka i djevojčica. Odnosno, rezultati regresijskih analiza pokazuju da višu razinu proaktivne i reaktivne agresivnosti iskazuju djevojčice i dječaci koji u većoj mjeri osjećaju antagonizam, natjecanje, svađe i dominaciju u odnosu sa sestrom. Na poduzorku djevojčica značajnim prediktorom reaktivne agresivnosti pokazala se još i dimenzija topline u odnosu sa sestrom.

\section{UVOD}

Odnos braće i sestara jedan je od temeljnih odnosa u životu svakog čovjeka naročito jer je to obično najdugotrajnija obiteljska veza. Brat i sestra su uz roditelje najbliži članovi obitelji i bez obzira u kakvom se odnosu nalazili (suparništvo, prijateljstvo) to je jedna od najdubljih emocionalnih veza. Dugotrajnost, kao i činjenica da braća i sestre osim genetskog naslijeđa dijele obiteljsko i sociokulturalno podrijetlo samo su neke od jedinstvenih karakteristika odnosa među braćom i sestrama. Tijekom života braća i sestre poprimaju različite uloge u životima jedni drugih; mogu biti antagonisti, prijatelji, zaštitnici i suradnici (Noller, 2005.). U kasnijim fazama života braća i sestre su rijetke osobe koje nas poznaju iz različitih razdoblja života i s kojima možemo razgovarati o vlastitoj stabilnosti i promjenama što pridonosi tome da nas braća i sestre bolje i lakše razumiju od drugih (Ćubela Adorić, 2006.). Sve to pridonosi dugotrajnosti i jedinstvenosti ovog bliskog odnosa. Unatoč ovim jedinstvenim karakteristikama, odnos između braće i sestara tek se sustavnije počeo proučavati zadnjih 40-ak godina i to prvenstveno u zapadnim industrijaliziranim zemljama. Kod nas, koliko je poznato, do sada nije bilo sustavnog istraživanja ovog bliskog odnosa u adolescenciji.

Prije nego što se objasne pozitivne i negativne karakteristike ovog odnosa, bitno je ponešto reći i zašto je nužno proučavanje istog. Naime, rezultati dosadašnjih istraživanja pokazuju da odnos među braćom i sestrama utječe na kognitivni, emocionalni i socijalni razvoj djece. Prisni odnosi s braćom i sestrama povezani su s razvojem socijalnih vještina, samootkrivanjem, empatičkim razumijevanjem (Bun Lam, Solmeyer i McHale, 2007.; Howe, Karos i Aquan-Assee, 2011.). Dunn (2000.) ističe da djeca koja imaju braću i sestre češće pokazuju prosocijalne oblike ponašanja, bolje prepoznaju i razumiju emocije drugih. Bedford i Volling (2004.) na osnovi niza istraživanja zaključuju da interakcija među braćom i sestrama čini 
pozitivan kontekst za razvoj aktivnih strategija suočavanja. Novija istraživanja u ovom području ukazuju na značajan doprinos kvalitetnog odnosa među braćom i sestrama psihološkoj dobrobiti pojedinca. U istraživanju koje je provela Stocker (1993.) utvrđeno je da je kvaliteta ovog odnosa povezana s mjerama depresivnosti, anksioznosti i samopoštovanja pri čemu pojedinci koji imaju kvalitetniji odnos s braćom i sestrama postižu više rezultate na mjeri samopoštovanja, a niže rezultate na mjerama depresivnosti i anksioznosti. Brojna su istraživanja koja pokazuju da je kvaliteta odnosa među braćom i sestrama i u dječjoj dobi i u adolescenciji povezana s internaliziranim kao i eksternaliziranim problemima kod djece (Richmond, Stocker i Reinks, 2005.; Volling, McElwain i Miller, 2005.). Pri tome se posebno ističe uloga starije braće i sestara pri čemu se djeca koja imaju stariju braću i sestre bolje prilagođavaju stresnim životnim događajima nego djeca koja nemaju stariju braću i sestre (Gass, Jenkins i Dunn, 2007.).

U ovom istraživanju fokusirat ćemo se samo na odnos koji djeca imaju sa sestrom budući da se ovaj odnos pokazao važnim za psihološku dobrobit pojedinca, kako u djetinjstvu i adolescenciji, tako i u odrasloj dobi. Cicirelli (1991.) je utvrdio da je percepcija bliskog odnosa sa sestrom i kod muškaraca i kod žena povezana s pokazateljima subjektivne dobrobiti i mentalnog zdravlja (konkretno, s nekim simptomima depresije) dok se bliska veza s bratom nije pokazala važnom za subjektivnu dobrobit. Cicirelli (1991.) smatra da ljudi zapravo imaju različita očekivanja od brata i sestre koja proizlaze iz tradicionalnih razlika između muškaraca i žena. Ovaj autor smatra, naime, da veća emocionalna ekspresivnost žena i njihova tradicionalna uloga odgajatelja objašnjavaju zašto je odnos sa sestrom bitan za subjektivnu dobrobit pojedinca. Žene slobodnije izražavaju svoje osjećaje, više se emocionalno uključuju u odnose s braćom i sestrama nego muškarci i to može biti vrlo važno za percepciju prisnosti u odnosu. Ako osobe percipiraju veći stupanj prisnosti, vrlo je vjerojatno da će se u kriznim situacijama obratiti upravo sestrama za pomoć, i ta percepcija sestara kao uvijek dostupnih rezervi za socijalnu potporu doprinosi subjektivnoj dobrobiti pojedinca. Istraživanja, također, pokazuju da je za subjektivnu dobrobit važnija percepcija dostupnosti sestre nego stvarne interakcije (kontakti) s njima (Cicirelli, 1991.).

\section{Braća i sestre u adolescenciji}

Razvoj u adolescenciji uključuje težnju za autonomijom - osjećajem sebe kao zasebne osobe koja upravlja sama sobom. Tinejdžeri teže oslanjati se više na sebe, a manje na roditelje za savjete i donošenje odluka. Sukladno tome, rezultati istraživanja pokazuju da se u djetinjstvu, djeca u najvećoj mjeri povjeravaju 
svojim roditeljima, no ulaskom u adolescenciju dolazi do značajnog opadanja povjeravanja istima što je povezano s razvojnim procesima individuacije i separacije karakterističnim za ovo razdoblje odrastanja (Buhrmester, 1992.). I odnosi između braće i sestara se, poput odnosa roditelja i djece u adolescenciji trebaju prilagoditi promjenama. Kada mlađi braća i sestre sazrijevaju i postaju neovisniji, dopuštaju manje usmjeravanja (podučavanje, skrb jednih o drugima, zajedničke aktivnosti) od starije braće i sestara te ne utječu u istoj mjeri jedni na druge kao u djetinjstvu (Feinberg, McHale, Crouter i Cumsille, 2003.). Odnos između braće i sestara postaje manje intenzivan, kako u pozitivnim tako i u negativnim interakcijama. Tinejdžeri postaju angažiraniji u prijateljstvima i romantičnim odnosima te ulažu manje vremena i energije u braću i sestre koji su dio obitelji i od kojih pokušavaju ostvariti autonomiju (Lacković Grgin, 2006.). Kako je prethodno spomenuto, u ovom razdoblju djeca istražuju svoj identitet, imaju značajnu potrebu pripadati određenoj vršnjačkoj grupi te sve manje vremena provode s braćom i sestrama. Zbog razvojnih promjena najčešće je ovo razdoblje povezano s percepcijom sve većih razlika između njih. No, privrženost među braćom i sestrama kao i bliskost s roditeljima usprkos smanjenom druženju za većinu mladih ostaje snažna. Braća i sestre čiji su roditelji topli i podržavajući i koji su uspostavili pozitivnu vezu u ranom djetinjstvu nastavljaju izražavati veću uzajamnu naklonost i brigu i tijekom tinejdžerskih godina.

Odnosi između braće i sestara u adolescenciji uključuju pomaganje, dijeljenje, poučavanje, igranje, ali i ratovanje. Brat i sestra mogu pružati emocionalnu i instrumentalnu potporu, mogu biti partneri u komunikaciji, ali i rivali. $U$ fokusu dosadašnjih istraživanja (Buhrmester, 1992.; Buhrmester i Furman, 1990.) odnosa između braće i sestara u djetinjstvu i adolescenciji najčešće su bili »prisnost« kao sastavnica pozitivne dimenzije tog odnosa te »konflikti«, »rivalstvo« $\mathbf{i}$ »percepcija statusa i moći« kao sastavnice negativne dimenzije odnosa između braće i sestara. Prva sustavna istraživanja o ovom razdoblju započeli su Furman i Buhrmester (1985.) što je na koncu rezultiralo i konstrukcijom jednog od najpoznatijih instrumenata za ispitivanje kvalitete ovog odnosa u adolescenciji (SRQ, Furman i Burhmester, 1985.). Kada je riječ o percepciji pozitivnih i negativnih aspekata odnosa u razvoju SRQ upitnika, krenulo se od pretpostavke da oni nisu opoziti na istom kontinuumu, odnosno da su toplina i konflikti dvije nezavisne dimenzije percepcije kvalitete odnosa između braće i sestara. Upitnik je prvi put primijenjen na učenicima šestog razreda ( $\mathrm{N}=200)$, a rezultati su pokazali da se kvaliteta odnosa među braćom i sestrama u ranoj adolescenciji može opisati kroz toplinu, konflikte, rivalstvo te status i moć. Kasnije primjene ovog upitnika pokazuju da se četiri identificirane dimenzije odnosa među braćom i sestrama doista mogu smatrati osnovnim karakteristikama ili dimenzijama odnosa između braće i sestara u adolescenciji. Dimenzija statusa i moći zapravo najviše ovisi o razvojnim promjenama djece. U mlađoj dobi (do 11

\section{6 članci}


i 12 godine) ova je dimenzija posebice izražena, a obično stariji brat/sestra ima veću moć. Nakon spomenute dobi ova dimenzija postaje manje izražena budući da roditelji sve manje traže od starije djece da brinu o mlađoj braći i sestrama. Buhrmester (1992.) ove promjene u odnosu vidi kao trend ili tendenciju k većoj egalitarnosti u odnosu, što je jedan od faktora koji odnos s braćom i sestrama čine sličnim odnosu s vršnjacima i prijateljima. Kada je riječ o rodnom sastavu dijade, rezultati brojnih istraživanja konvergiraju prema zaključku da je veća kvaliteta ovog odnosa (veća percepcija prisnosti, potpore, razumijevanja) utvrđena kod sestara, a najmanja kod braće (Buhrmester, 1992.; Furman i Buhrmester, 1985.; Kim, Mchale, Osgood i Crouter, 2006.; Scharf, Shulman i Avigad-Spitz, 2007.). Izgleda da odnos sa sestrom doista mijenja percepciju pojedinih (prvenstveno pozitivnih) aspekata odnosa; ove razlike pripisuju se većoj empatičnosti, emocionalnosti i kooperativnosti djevojčica što onda utječe i na odnos među braćom i sestrama.

\section{Agresivno ponašanje i kvaliteta odnosa među braćom i sestrama}

Agresivnim ponašanjem smatra se svako ponašanje izvedeno s namjerom da se nekomu ili nečemu nanese bilo kakva povreda ili šteta. Oblici agresivnog ponašanja mjereni u istraživanju koje će biti prikazano obuhvaćaju reaktivnu i proaktivnu agresivnost i predstavljaju ponašanja koja su normalna za djecu u razdoblju rane adolescencije. Razlika između reaktivne i proaktivne agresivnosti najčešće se uočava u školskoj dobi. Reaktivno agresivno ponašanje javlja se kao reakcija na određene situacijske uvjete i najčešće je popraćeno intenzivnim fiziološkim uzbuđenjem te snažnom emocijom srdžbe. Pojam reaktivne agresivnosti djelomično se preklapa s pojmovima emocionalne i hostilne agresije. Proaktivno agresivno ponašanje jest ono do kojeg dolazi zbog anticipacije nekog poželjnog cilja koji se može ostvariti agresivnim ponašanjem. Ovo agresivno ponašanje nastaje bez provokacije uz znatno slabije fiziološko uzbuđenje i najčešće se preklapa s pojmom instrumentalne agresije. Proaktivno agresivnu djecu u literaturi se slikovito opisuje kao onu koja su »problem za druge«, a reaktivno agresivnu kao onu kojoj su »druga djeca problem« (Keresteš, 2002.). Unatoč nekim individualnim razlikama u reaktivnoj i proaktivnoj agresivnosti, većina agresivnih pojedinaca manifestira i jednu i drugu vrstu agresivnosti. Razvoj agresivnih oblika ponašanja kod djece povezuje se s obiteljskim procesima i to prvenstveno s kvalitetom obiteljskih interakcija koja se najčešće operacionalizira kroz različite dimenzije roditeljskog ponašanja (Brody, 1998.). Tako se s agresivnim ponašanjem povezuju grubi i nedosljedni postupci roditeljskog discipliniranja, puno prijetnji, naređivanja i kažnjavanja kao i permisiv- 
nost roditelja prema djetetovoj agresivnosti. Najkonzistentniji nalazi dobiveni su za dimenziju prihvaćanja/odbijanja; djeca čiji su roditelji emocionalno topliji manje su agresivna od djece odbijajućih i emocionalno hladnih roditelja. S druge strane, nalazi oko kontrole dječjeg ponašanja su kontradiktorni; nalazi nekih istraživanja upućuju na zaključak da je postavljanje jasnih pravila i granica ponašanja povezano s manjom razinom agresivnosti kod djece dok druga istraživanja pokazuju da je čvrsta bihevioralna i psihološka kontrola povezana s više agresivnog ponašanja (Keresteš, 2001., 2002.).

Odnos između agresivnosti i kvalitete odnosa među braćom i sestrama nije jednostavan. Naime, interakcije među braćom i sestrama (natjecanje za roditeljskom pažnjom, percepcija nejednakog statusa, dječji konflikti) mogu poticati razvoj agresivnosti kod djece. Također, neka istraživanja pokazuju da je veća vjerojatnost nastanka agresivnog ponašanja kod djece koja imaju agresivnu braću i sestre (Ostrov, Crick i Stauffacher, 2006.). U prilog pretpostavci o negativnim implikacijama agresivnog ponašanja na razvoj bliskog odnosa među braćom i sestrama idu i rezultati istraživanja koje su proveli Updegraff i sur. (2005.). Rezultati provedenog istraživanja pokazuju da je agresivno ponašanje kod djece u pozitivnoj vezi s percepcijom negativnih aspekata odnosa među braćom i sestrama, dok je suprotan smjer povezanosti dobiven za percepciju pozitivnih aspekata odnosa. Sukladno tome, utvrđen je značajan pozitivan doprinos agresivnosti u percepciji negativnih aspekata odnosa među braćom i sestrama, odnosno agresivnost se pokazala negativnim prediktorom intimnosti u odnosu s bratom i sestrom. Nije bilo značajnih razlika u povezanosti agresivnosti i kvalitete odnosa među braćom i sestrama kod dječaka i djevojčica. Percepcija nejednakog odnosa roditelja prema djeci pokazala se značajnim prediktorom agresivnosti i kod dječaka i djevojčica. Slični rezultati dobiveni su i u istraživanju koje su proveli Kramer i Kowal (2005.); djeca koja postižu više rezultate na mjeri agresije percipiraju više sukoba i rivalstva, a manje topline u odnosu s bratom i sestrom u usporedbi s djecom koja postižu niže rezultate na mjeri agresivnog ponašanja. Nadalje, konfliktan odnos među braćom i sestrama značajan je prediktor agresivnosti u prijateljskim vezama i lošijeg školskog uspjeha. Ova veza prvenstveno je utvrđena kod djece koja postižu više rezultate na mjerama agresivnosti. Izgleda da će odnos između braće i sestara imati negativne implikacije na prilagodbu pojedinca i to prvenstveno kod rizične skupine djece; npr. kod agresivne djece, djece s teškim temperamentom. Moguće je da će agresivna djeca zbog vlastita ponašanja (prema prijateljima, braći i sestrama, roditeljima) imati i manje mogućnosti za usvajanje adaptivnih socijalnih vještina (Stormshak, Bellanti i Bierman, 1996.). Slični rezultati o odnosu između agresivnog ponašanja i odnosa među braćom i sestrama dobiveni su i u studiji koju su proveli Aguilar i suradnici (2001.); interakcije agresivne djece obilježene su sa značajno više konflikata i agresivnog ponašanja u usporedbi sa sudionicima koji postižu niže rezultate na mjerama agresivnosti.

\section{8 članci}




\section{CILJ, PROBLEMI I HIPOTEZE ISTRAŽIVANJA}

Kako bi se unaprijedile spoznaje o važnosti odnosa sa sestrom na djetetovo doživljavanje, ponašanje i razvoj u okviru ovog istraživanja ispitat će se uloga dječje percepcije kvalitete odnosa sa sestrom u objašnjenju specifičnih problema dječjeg psihosocijalnog funkcioniranja. Konkretnije, utvrdit će se rodne razlike u percepciji kvalitete odnosa sa sestrom i manifestaciji proaktivne i reaktivne agresivnosti. Na temelju postojećih istraživanja u ovom području može se očekivati kvalitetniji odnos u istorodnim dijadama (sestra - sestra) u usporedbi s mješovitim (brat - sestra) i pojačani problemi u ponašanju kod dječaka. Nadalje, ispitat će se doprinos dječje percepcije pojedinih dimenzija kvalitete odnosa sa sestrom (topline koja obuhvaća percepciju ljubavi, prisnosti, suradnje, sličnosti, divljenja i druženja u odnosu sa sestrom, konflikata koji obuhvaćaju percepciju svađa, natjecanja, antagonizma i dominacije u odnosu sa sestrom i rivalstva koje obuhvaća percepciju majčina favoriziranja u odnosu sa sestrom) u objašnjenju zastupljenosti eksternaliziranih problema (reaktivne i proaktivne agresivnosti) kod mlađih adolescenata. Pretpostavlja se da na dječje psihosocijalno funkcioniranje nepovoljno utječu dječji sukobi i percepcija majčina favoriziranja te se očekuje značajan pozitivan doprinos percipirane učestalosti sukoba sa sestrom i majčina favoriziranja u objašnjenju dječjih problema eksternaliziranog tipa. Sukladno nalazima prethodnih istraživanja, percepcija topline u odnosu sa sestrom bit će negativan prediktor agresivnosti u ranoj adolescenciji.

\section{METODOLOGIJA ISTRAŽIVANJA}

\section{Sudionici istraživanja}

Jedan od glavnih problema u istraživanjima odnosa između braće i sestara jest odabir odnosa koji će sudionik procjenjivati. Istraživači se najčešće usmjeravaju na procjenu odnosa s onim bratom ili sestrom koji je sudioniku najbliži po godinama ili procjenu odnosa s onim bratom ili sestrom s kojim sudionik ima najbolji odnos. Ograničavajući uzorak na gore navedene nije moguće obuhvatiti široke varijacije u kvaliteti ovog odnosa te dinamične procese i probleme u bratskim i/ili sestrinskim odnosima koje doprinose kvaliteti funkcioniranja cijele obitelji. Uzimajući u obzir činjenicu da se odnos među braćom i sestrama razlikuje ovisno o tome dijele li braća i sestre istu obiteljsku klimu te s obzirom na specifičnosti ovog odnosa u adolescenciji, u ovom istraživanju fokusirali smo se na odnos koji učenici i učenice sedmih i osmih razreda imaju sa sestrom koja i dalje živi u istom kućanstvu s njima. 
Selekcionirajući prigodni uzorak na ovaj način, nastojalo se osigurati da djeca obuhvaćena ovim istraživanjem procjenjuju odnos sa sestrom koja živi s njima te da je njihov međusoban odnos dio složenih obiteljskih interakcija i dinamike. U slučaju kad je sudionik imao više sestara koje su mlađe ili starije od njega, procjenjivao je odnos sa sestrom koja mu je bliža po godinama. S obzirom na selekcijsku prirodu uzorka kao i činjenicu da $40 \%$ roditelja nije dalo pristanak za sudjelovanje njihove djece $u$ istraživanju, tolerirali smo do 5 godina razliku u dobi između sudionika i njegove starije sestre vodeći se pritom kriterijem da sestra i dalje živi u istom kućanstvu. Kada je riječ o mlađoj sestri, tolerirali smo i razliku do 6 godina.

U konačnici, ovim istraživanjem obuhvaćeno je 352 djece u dobi od 13 do 15 godina. Ukupno je sudjelovalo 192 djevojčice $(54,4 \%)$ i 160 dječaka $(45,3 \%)$, a od toga je njih 163 učenika (46,6\%) 7. razreda i 188 učenika $(53,4 \%)$ 8. razreda. Jedna podskupina sudionika procjenjivala je odnos sa starijom sestrom ( $N=181,51,7 \%)$, a druga s mlađom sestrom $(\mathrm{N}=171,48,3 \%)$. Nije bilo statistički značajne razlike $\mathrm{u}$ broju djevojčica i dječaka unutar ovih podskupina $\left(x^{2}=2,02, d f=1, p>0,05\right)$. Prosječna dob sestre (odnos koji je sudionik procjenjivao) bila je 13,86 (SD =4,089). Prosječna dob procjenjivane starije bila je oko 17 godina $(M=17,38, S D=1,546) \mathrm{u}$ rasponu od 14 do 20 godina, dok je prosječna dob procjenjivane mlađe sestre bila oko 10 godina ( $M=10,14, S D=2,048)$ u rasponu od 6 do 15 godina. Broj sestara varirao je od $1-12(M=1,51, S D=1,000)$, a broj braće od 0 do $10(M=0,80, S D=$ 1,049). Najveći broj djece je prvorođeno (30\%), odnosno drugorođeno (29\%) dijete u obitelji.

\section{Mjerni instrumenti}

U istraživanju je primijenjen upitnik općih podataka o sudioniku koji je sadržavao pitanja o rodu, dobi, razredu, broju braće i sestara te sljedeći mjerni instrumenti:

1. Upitnik o odnosima među braćom i sestrama (The Sibling Relationship Questionnaire, Furman i Buhrmester, 1985.).

2. Skala agresivnosti AG (Keresteš, 1999.).

\section{Upitnik o odnosima među braćom i sestrama (The Sibling Relationship Questionnaire, Furman i Buhmester, 1985.)}

Upitnik o odnosima među braćom i sestrama sastoji se od ukupno 48 tvrdnji koje opisuju različite pozitivne (npr. ljubav, prisnost, sličnost) i negativne aspekte (npr. natjecanje, antagonizam) odnosa među braćom i sestrama. Analize latentne 
strukture cijelog upitnika gdje je kao ulazna matrica bila matrica korelacija među pojedinim skalama rezultirale su trofaktorskom solucijom koja objašnjava oko $60 \%$ zajedničke varijance. Na prvoj izlučenoj komponenti visoka zasićenja $(>0,50)$ imaju skale koje opisuju pozitivne aspekte odnosa sa sestrom. Ova prva komponenta odgovara dimenziji koju su Furman i Buhrmester (1985.) nazvali »toplina«. Visoka zasićenja na drugom izlučenom faktoru imaju skale koje opisuju negativne aspekte odnosa s bratom ili sestrom, a odgovara dimenziji koju autori (Furman i Buhrmester, 1985.) nazivaju »konflikti« i objašnjava 37\% zajedničke varijance. Treći faktor objašnjava $8 \%$ zajedničke varijance i odgovara dimenziji »rivalstva«, jer značajno i vrlo visoko zasićenje na njemu ima samo skala majčina favoriziranja. Ukupni rezultat na skali (dimenziji) topline prosječna je vrijednost procjena dobivenih na skalama koje opisuju pozitivne aspekte odnosa sa sestrom. Ukupni rezultat na skali konflikata prosječna je vrijednost procjena dobivenih na skalama koje opisuju negativne aspekte odnosa. Teoretski, raspon rezultata na skalama topline i konflikata može varirati od 1 do 5 . Distribucija rezultata na skali topline u ovom istraživanju pomaknuta je prema višim vrijednostima, dok je distribucija rezultata na skali konflikata pomaknuta prema nižim vrijednostima što je i očekivano kada je riječ o odnosu između braće i sestara. Za obje skale utvrđeni su zadovoljavajući koeficijenti pouzdanosti izraženi Cronbach alfom koji za skalu topline iznosi 0,90 a za subskalu konflikata 0,80 . Na skali majčina favoriziranja čestice se formulirane tako da sudionik prvo procjenjuje odnos majke prema sudioniku (npr. »Koliko prema tvom mišljenju tvoja majka podržava tebe?«), a potom procjenjuje odnos majke prema sestri (npr. »Koliko prema tvom mišljenju tvoja majka podržava sestru?«). Cilj je utvrditi apsolutnu razliku procjena koje je sudionik dao za sebe i sestru (tako dobijemo informaciju o favoriziranju, bez obzira na smjer). Rezultati na ovom indeksu ili mjeri razlike mogu varirati između 0 i 4 pri čemu veći rezultat implicira veće favoriziranje. Dobiveni raspon rezultata na ovoj skali manji je od teoretskog. U skladu s time su i parametri srednjih vrijednosti (npr. $M=0,22)$ koji ukazuje da djevojčice i dječaci percipiraju malo majčina favoriziranja u odnosu sa sestrom. Koeficijenti pouzdanosti izražen Cronbach alfom za ovu skalu iznosi 0,74.

\section{Skala agresivnosti AG (Keresteš, 1999.)}

Skala agresivnosti sastoji se od 15 čestica kojima se mjeri reaktivna i proaktivna agresivnost. Subskala reaktivne agresivnosti sastoji se 7 čestica i (primjer čestice: »Kad me netko udari, vratim mu istom mjerom.«) dok se subskala proaktivne agresivnosti sastoji od 8 čestica (primjer čestice: »Kad u školi stojimo u redu, volim gurati one oko sebe«). Ukupan rezultat na pojedinoj subskali formiran je kao prosječan rezultat na pripadajućim česticama. Mogući teoretski raspon rezultata 
kreće od 1 do 4 pri čemu veći rezultat ukazuje i na veću agresivnost. Provjerom latentne strukture Skale AG u ovom istraživanju potvrđena je dvofaktorska struktura skale, pri čemu dobivena solucija objašnjava preko $50 \%$ varijance čestice. Za obje subskale utvrđeni su visoki koeficijenti pouzdanosti izraženi Cronbach alfom koji za subskalu reaktivne agresivnosti iznosi 0,86 , a za subskalu proaktivne agresivnosti 0,90 . Distribucije rezultata na pojedinim subskalama su pozitivno asimetrične i većina se rezultata grupira oko nižih vrijednosti što je i očekivano kada je riječ o samoiskazima agresivnog ponašanja.

\section{Postupak istraživanja}

Ukupno je istraživanjem obuhvaćeno preko 50 razrednih odjeljenja iz osnovnih škola iz Zadra, Splita i Šibenika uz prethodno odobrenje Etičkog povjerenstva Sveučilišta u Zagrebu kao i ravnatelja svake škole. S obzirom na to da su u istraživanju mogli sudjelovati samo oni učenici koji imaju stariju ili mlađu sestru, psiholog je u dogovoru s predmetnim nastavnicima proveo pismenu anketu s ciljem dobivanja informacija o broju i dobi braće i sestara učenika iz pojedinih razrednih odjeljenja. Konkretnije, učenici su u anketi odgovarali na pitanja: »Koliko imaš sestara?«, »Koliko godina imaju tvoje sestre?«. Na osnovu dobivenih informacija glavni istraživač je pripremio upitnike te dogovorio primjenu istih samo za one učenike koji su udovoljavali kriterijima za odabir uzorka, odnosno za djecu koja su dobila pismeni pristanak roditelja i koja su dobrovoljno sama pristala na istraživanje. Konkretno, $\mathrm{u}$ istraživanje su uključeni učenici i učenice sedmih i osmih razreda koji su imali do 5 godina stariju sestru te učenici i učenice koji su imali do 6 godina mlađu sestru. Pritom se vodilo računa da bude podjednak broj dječaka i djevojčica te podjednak broj učenika koji će procjenjivati odnos sa starijom, odnosno mlađom sestrom. Istraživanje se odvijalo uglavnom na satovima razredne nastave i trajalo je jedan školski sat.

\section{REZULTATI}

\section{Razlike između djevojčica i dječaka}

U Tablici 1 razmatrani su rezultati t-testova za nezavisne uzorke, odnosno provjereni su efekti roda djeteta na percepciju kvalitete odnosa sa sestrom te procjenu zastupljenosti simptoma agresivnosti (proaktivne i reaktivne).

\section{2 članci}


M. Jurkin, J. Ombla: Rodne razlike u percepciji odnosa sa sestrom i manifestaciji proaktivne...

Tablica 1. Deskriptivna statistika te vrijednosti t-testova za ispitivanje razlika između dječaka i djevojčica ( $\mathrm{N}=352)$

\begin{tabular}{lccccc}
\hline \multirow{2}{*}{ Skala } & \multicolumn{2}{c}{ Dječaci } & \multicolumn{2}{c}{ Djevojčice } & \multirow{2}{*}{ t } \\
\cline { 2 - 5 } & $\mathbf{M}$ & SD & $\mathbf{M}$ & $\mathbf{S D}$ & \\
\hline Toplina & 3,50 & 0,69 & 3,79 & 0,64 & $-3,967^{* *}$ \\
\hline Konflikti & 2,61 & 0,81 & 2,70 & 0,83 & $-1,012$ \\
\hline Majčino favoriziranje & 0,18 & 0,35 & 0,25 & 0,47 & $-1,746$ \\
\hline Proaktivna agresivnost & 1,63 & 0,65 & 1,45 & 0,62 & $2,590^{*}$ \\
\hline Reaktivna agresivnost & 2,21 & 0,66 & 1,90 & 0,71 & $4,242^{* *}$ \\
\hline
\end{tabular}

${ }^{*} p<0,05,{ }^{* *} p<0,01$

U usporedbi s dječacima, djevojčice percipiraju značajno više topline u odnosu sa sestrom $\left(M_{\check{z}}=3,8, M_{m}=3,5\right)$. Na dimenzijama konflikti i majčino favoriziranje nisu utvrđene značajne razlike s obzirom na rod. Kada je riječ o mjerama prilagodbe, sukladno očekivanjima, dječaci postižu značajno više rezultate na mjerama proaktivne i reaktivne agresivnosti.

\section{Korelacijske analize}

S obzirom na to da je rod djeteta relevantan čimbenik u psihosocijalnom funkcioniranju, te da su u ovom istraživanju utvrđene značajne razlike u percepciji kvalitete odnosa sa sestrom u mješovitim $\mathrm{i}$ istorodnim dijadama, rezultati odnosa kvalitete odnosa sa sestrom i mjera agresivnog ponašanja zasebno su analizirani na uzorku djevojčica i dječaka. Zasebnim obradama na poduzorku djevojčica i dječaka cilj je bio utvrditi da li je kvaliteta odnosa sa sestrom povezana s psihosocijalnim funkcioniranjem u mješovitim i istorodnim dijadama. Većina korelacija između analiziranih varijabli u ovom istraživanju je niske do umjerene veličine. Nešto veće vrijednosti koeficijenata korelacije dobivene su između pojedinih pozitivnih i negativnih aspekata odnosa među braćom i sestrama dok su skromne povezanosti između majčina favoriziranja i mjera agresivnosti.

U Tablici 2 prikazani su koeficijenti bivarijatnih korelacija među svim analiziranim varijablama u ovom istraživanju utvrđenih na uzorku dječaka $(\mathrm{N}=160$, ispod dijagonale) i uzorku djevojčica ( $N=192$, iznad dijagonale). 
Tablica 2. Korelacije ispitivanih varijabli na uzorku dječaka $(N=160)$ i djevojčica $(\mathrm{N}=192)$

\begin{tabular}{llccccc}
\hline & & $\mathbf{1 .}$ & $\mathbf{2 .}$ & $\mathbf{3 .}$ & $\mathbf{4 .}$ & $\mathbf{5 .}$ \\
\hline 1. & Toplina & - & $-0,38^{* *}$ & $-0,24^{* *}$ & $-0,24^{* *}$ & $-0,32^{* *}$ \\
\hline 2. & Konflikti & $-0,19^{* *}$ & - & $0,23^{* *}$ & $0,42^{* *}$ & $0,50^{* *}$ \\
\hline 3. & Majčino favoriziranje & $-0,18^{* *}$ & $0,12^{*}$ & - & $0,12^{*}$ & $0,18^{* *}$ \\
\hline 4. & Proaktivna agresivnost & $-0,10$ & $0,39^{* *}$ & $0,18^{* *}$ & - & $0,81^{* *}$ \\
\hline 5. & Reaktivna agresivnost & $-0,08$ & $0,24^{* *}$ & $0,14^{*}$ & $0,53^{* *}$ & - \\
\hline
\end{tabular}

Napomena: iznad dijagonale su rezultati dobiveni na uzorku djevojčica ${ }^{*} p<0,05,{ }^{* *} p<0,01$

U skladu s pretpostavkama, utvrđene su značajne relacije između pojedinih dimenzija kvalitete odnosa sa sestrom u mješovitim i istorodnim dijadama. Dakle, djeca koja izvještavaju o višim razinama učestalih međusobnih sukoba sa sestrom percipiraju manje topline u tom odnosu. Također, djeca koja u većoj mjeri osjećaju favoriziranje od strane majke percipiraju manje topline u odnosu sa sestrom. Dvije mjere negativnih aspekata odnosa (konflikti i majčino favoriziranje) u pozitivnim su međusobnim korelacijama i u mješovitim i istorodnim dijadama, odnosno djeca koja percipiraju više sukoba u odnosu sa sestrom percipiraju i više favoriziranja od strane majke (Tablica 2).

Kada je riječ o odnosu između pojedinih dimenzija kvalitete odnosa sa sestrom i mjera agresivnosti, dobiveni su nešto drugačiji rezultati na uzorku dječaka i djevojčica. Na uzorku dječaka jedino negativni aspekti kvalitete odnosa sa sestrom značajno i pozitivno koreliraju s obje mjere agresivnog ponašanja; dječaci koji izvještavaju o višim razinama učestalog sukoba sa sestrom imaju više simptoma proaktivne i reaktivne agresivnosti. Nešto skromnija, ali ipak značajna korelacija na poduzorku dječaka utvrđena je između majčina favoriziranja i mjera agresivnosti. Dječaci koji u većoj mjeri osjećaju favoriziranje od strane majke imaju više rezultate na mjerama agresivnosti. Kod djevojčica pojedine dimenzije kvalitete odnosa sa sestrom u značajnim su korelacijama s obje mjere agresivnosti; pritom su nešto više korelacije s reaktivnom agresivnosti. Toplina kao mjera pozitivnih aspekata odnosa sa sestrom u značajnim je i negativnim korelacijama s obje mjere agresivnosti; dakle, više rezultate ne mjerama agresivnosti imaju djevojčice koje percipiraju manje topline u odnosu sa sestrom. Konflikti i rivalstvo kao mjere negativnih aspekata odnosa sa sestrom pozitivno koreliraju s proaktivnom i reaktivnom agresivnosti. Djevojčice koje percipiraju više sukoba i rivalstva u odnosu sa sestrom agresivnije su.

\section{4 članci}


M. Jurkin, J. Ombla: Rodne razlike u percepciji odnosa sa sestrom i manifestaciji proaktivne...

\section{Regresijske analize}

Kako bi se ispitao doprinos različitih dimenzija kvalitete odnosa među braćom i sestrama u objašnjenju agresivnosti, provedene su standardne regresijske analize (zasebno na uzorku dječaka i djevojčica). Prediktorske varijable bile su dječje procjene dimenzija kvalitete odnosa sa sestrom (toplina, konflikti i majčino favoriziranje), a procjene reaktivne i proaktivne agresivnosti kriterijske varijable (Tablice 3 i 4).

Dimenzije kvalitete odnosa među braćom i sestrama imaju značajan relativan doprinos objašnjenju eksternaliziranih problema (proaktivna i reaktivna agresivnost) kod dječaka i djevojčica. Zadani skup prediktorskih varijabli objašnjava oko $15 \%$ varijance proaktivne agresivnosti kod dječaka, odnosno 17\% kod djevojčica. Značajni prediktor proaktivne agresivnosti i kod dječaka i kod djevojčica je dimenzija konflikti. Višu razinu proaktivne agresivnosti imaju djevojčice i dječaci koji procjenjuju da su konflikti sa sestrom češći. Nadalje, dimenzije kvalitete odnosa među braćom i sestrama objašnjavaju oko $5 \%$ varijance reaktivne agresivnosti kod dječaka, odnosno $26 \%$ kod djevojčica. Jedinim značajnim prediktorom ove mjere agresivnosti kod dječaka pokazala se dimenzija konflikti; višu reaktivnu agresivnost pokazuju dječaci koji procjenjuju da su konflikti sa sestrom češći. Kod djevojčica značajni nezavisni prediktori u objašnjenju reaktivne agresivnosti su dimenzije toplina i konflikti. Višu razinu reaktivne agresivnosti imaju djevojčice koje procjenjuju da su konflikti sa sestrom češći, odnosno djevojčice koje percipiraju manje topline u odnosu sa sestrom.

Tablica 3. Rezultati standardnih regresijskih analiza ( $\beta$-standardizirani regresijski koeficijenti) s toplinom, konfliktima i majčinim favoriziranjem kao prediktorima te proaktivnom agresivnošću kao kriterijem na uzorku dječaka $(N=160)$ i djevojčica $(\mathrm{N}=192)$

\begin{tabular}{|c|c|c|c|c|c|}
\hline \multicolumn{6}{|c|}{ Dječaci } \\
\hline Kriterij & Prediktori & Beta & $\mathbf{t}$ & $\mathbf{p}$ & \\
\hline \multirow{3}{*}{$\begin{array}{l}\text { Proaktivna } \\
\text { agresivnost }\end{array}$} & Toplina & $-0,00$ & $-0,079$ & 0,937 & $R=0,41$ \\
\hline & Konflikti & 0,37 & 4,931 & 0,000 & $\mathrm{R}^{2}=0,15$ \\
\hline & Majčino favoriziranje & 0,13 & 1,772 & 0,078 & $\mathrm{~F}=10,36^{* *}$ \\
\hline \multicolumn{6}{|c|}{ Djevojčice } \\
\hline Kriterij & Prediktori & Beta & $\mathbf{t}$ & $\mathbf{p}$ & \\
\hline \multirow{3}{*}{$\begin{array}{l}\text { Proaktivna } \\
\text { agresivnost }\end{array}$} & Toplina & 0,09 & $-1,203$ & 0,231 & $R=0,42$ \\
\hline & Konflikti & 0,39 & 5,288 & 0,000 & $\mathrm{R}^{2}=0,17$ \\
\hline & Majčino favoriziranje & 0,00 & 0,136 & 0,892 & $F=13,86^{* *}$ \\
\hline
\end{tabular}

${ }^{*} \mathrm{p}<0,05,{ }^{* *} \mathrm{p}<0,01$ 
Tablica 4. Rezultati standardnih regresijskih analiza ( $\beta$-standardizirani regresijski koeficijenti) s toplinom, konfliktima i majčinim favoriziranjem kao prediktorima te reaktivnom agresivnošću kao kriterijem na uzorku dječaka $(N=160)$ i djevojčica $(\mathrm{N}=192)$

\begin{tabular}{|c|c|c|c|c|c|}
\hline \multicolumn{6}{|c|}{ Dječaci } \\
\hline Kriterij & Prediktori & Beta & $\mathbf{t}$ & $\mathbf{p}$ & \\
\hline \multirow{3}{*}{$\begin{array}{l}\text { Reaktivna } \\
\text { agresivnost }\end{array}$} & Toplina & $-0,01$ & $-0,151$ & 0,880 & $R=0,27$ \\
\hline & Konflikti & 0,23 & 2,886 & 0,004 & $R^{2}=0,05$ \\
\hline & Majčino favoriziranje & 0,10 & 1,327 & 0,186 & $\mathrm{~F}=3,92^{* *}$ \\
\hline \multicolumn{6}{|c|}{ Djevojčice } \\
\hline Kriterij & Prediktori & Beta & $\mathbf{t}$ & $\mathbf{p}$ & \\
\hline \multirow{3}{*}{$\begin{array}{l}\text { Reaktivna } \\
\text { agresivnost }\end{array}$} & Toplina & $-0,15$ & $-2,113$ & 0,036 & $R=0,52$ \\
\hline & Konflikti & 0,43 & 6,361 & 0,000 & $R^{2}=0,26$ \\
\hline & Majčino favoriziranje & 0,04 & 0,630 & 0,529 & $\mathrm{~F}=23.14^{* *}$ \\
\hline
\end{tabular}

${ }^{*} p<0,05, * * p<0,01$

\section{RASPRAVA}

U ovom radu su se analizirale rodne razlike u dječjoj percepciji kvalitete odnosa sa sestrom te rodne razlike u manifestaciji proaktivne i reaktivne agresivnosti. Glavni cilj provedenog istraživanja bio je ispitati ulogu dječje percepcije kvalitete odnosa sa sestrom u objašnjenju proaktivne i reaktivne agresivnosti kod mlađih adolescenata. Razdoblje rane adolescencije predstavlja intenzivno razdoblje razvoja u kojem je zbog značajnih promjena u različitim aspektima funkcioniranja prisutan povećan rizik za pojavu specifičnih problema dječjeg psihosocijalnog funkcioniranja.

Ukratko, rezultati i ovog istraživanja potkrepljuju nalaze o tome da su percepcija topline, konflikata i majčina favoriziranja važne sastavnice odnosa među braćom i sestrama u adolescenciji. Dimenzija »statusa/moći« u ovom istraživanju nije se pokazala važnom karakteristikom ovog odnosa što je u skladu s pretpostavkama kako u ranoj adolescenciji braća i sestre obično vide veću jednakost u odnosu te i ova dimenzija postaje manje salijentna (npr. Buhrmester, 1992.). Kada je riječ o rodnom sastavu dijade, glavni efekt roda sudionika pokazao se značajnim na dimenziji toplina. U usporedbi s dječacima, djevojčice percipiraju značajno više topline u odnosu sa sestrom. Nisu utvrđene značajne razlike između dječaka i djevojčica na mjerama negativnih (konflikti i majčino favoriziranje) aspekata odnosa među sa sestrom. Ovi rezultati samo su još jedan dokaz pretpostavke o većoj kva-

\section{6 članci}


liteti odnosa među sestrama u usporedbi s drugim tipovima dijade (konkretnije u ovom istraživanju mješovitim dijadama) (npr. Kim i sur., 2006.; Scharf i sur., 2007.). U istraživanju koje su proveli Furman i Buhrmester (1985.) više prisnosti, druženja suradnje i sličnosti percipirano je kod istorodnih dijada (u usporedbi s mješovitim), no samo kod onih dijada gdje je razlika u godinama između braće i sestara bila oko četiri godine (slično kao u našem istraživanju). $U$ spomenutom istraživanju nisu utvrđene rodne razlike u percepciji konflikata u odnosu između braće i sestara dok je glavni efekt razlike u godinama bio značajan. Zanimljiv je i smjer značajnosti; djeca su percipirala više antagonizma, svađanja i natjecanja u dijadama gdje je razlika u godinama bila manja od četiri. Kada usporedimo rezultate na mjerama topline i konflikata, može se primijetiti da je percepcija topline i konflikata najizraženija baš kod braće i sestara koja su bliža po godinama. Ovi rezultati također idu u prilog pretpostavci o tome da pozitivni i negativni aspekti odnosa nisu opoziti na istom kontinuumu, te da neovisno o toplini koju percipiramo u tom odnosu, možemo brata i sestru percipirati kao natjecatelja i antagonistu.

Brojna istraživanja ukazuju kako je rod djeteta relevantan čimbenik u psihosocijalnom funkcioniranju djeteta, odnosno da su eksternalizirani problemi češće izraženi kod dječaka (Archer, 2004.; Cole i sur., 2002.; Zahn-Waxler, Klimes-Dougan, Slattery, 2000.). Dobiveni rezultati ovog istraživanja ukazuju na veću zastupljenost reaktivne i proaktivne agresivnosti kod dječaka. S obzirom na samu prirodu konstrukta, možemo reći da su rezultati očekivani i u skladu s rezultatima dosadašnjih istraživanja. Dječaci još od malih nogu pokazuju više ponašanja koja uključuju silu i to na hostilan i instrumentalan način te općenito iskazuju više impulzivnosti, borbenosti i drugih nekontroliranih ponašanja.

Dječje psihosocijalno funkcioniranje može se objasniti većim brojem osobnih i okolinskih - obiteljskih čimbenika. Dosadašnja istraživanja naglašavala su ulogu roditeljskog ponašanja u nastanku agresivnog ponašanja, no rezultati ovog istraživanja jasno pokazuju da su i drugi aspekti obiteljskih procesa, konkretnije odnosi između braće i sestara, važni u objašnjenju agresije. Zbog čestih interakcija, konflikata i blagih fizičkih obračuna odnos između braće i sestara može biti i povoljan kontekst za razvoj agresije kod djece. Također, jedinstvene karakteristike ovog odnosa povećavaju vjerojatnost da će upravo braća i sestre biti modeli za buduća ponašanja (Buist, 2010.). Pritom važnu ulogu imaju roditelji i strategije koje koriste za upravljanje konfliktima među braćom i sestrama (Ostrov i sur., 2006.). Roditeljsko nekonstruktivno interveniranje u sukobe među braćom i sestrama (poput prijetnji, povišenog tona razgovora, prekidanja dječje svađe i fizičkog kažnjavanja) mehanizmima socijalnog učenja povećava vjerojatnost razvoja agresivnosti kod djece jer djeca kroz interakcije s roditeljima modeliraju svoje ponašanje (Felson i Russo, 1988.). Kada se djeca suoče s averzivnim događajem, kao što su npr. kon- 
flikti u obitelji (s roditeljima, braćom), ona najčešće koriste one strategije rješavanja konflikata koje u njihovim obiteljima dovode do prestanka sukoba (u nekim obiteljima sukob se riješi razgovorom, iskazivanjem empatije, a u drugim fizičkim kontaktima i svađanjem). Ponašanje, kojim se konflikt riješi, dobiva na snazi i veća je vjerojatnost da će isto koristiti i u ostalim konfliktnim situacijama i okruženjima izvan obitelji. Podaci nekih longitudinalnih studija o vrlo sličnoj manifestaciji problema eksternaliziranog tipa kao i antisocijalnih oblika ponašanja kod braće i sestara u periodu adolescencije još jedan su dokaz o utjecaju braće i sestara u ovoj dobi (McHale, Updegraff i Whiteman, 2012.).

Konkretno, rezultati ovog istraživanja ukazuju da je najznačajniji prediktor proaktivne agresivnosti kod djevojčica i dječaka dimenzija konflikata; višu razinu proaktivne agresivnosti navode djevojčice i dječaci koji procjenjuju da su konflikti sa sestrom češći, odnosno višu razinu proaktivne agresivnosti iskazuju djevojčice i dječaci koji u većoj mjeri osjećaju antagonizam, natjecanje, svađe i dominaciju u odnosu sa sestrom. Dimenzija konflikata izdvojila se kao značajan i nezavisan prediktor reaktivne agresivnosti i kod dječaka i kod djevojčica, odnosno više reaktivne agresivnosti iskazuju djevojčice i dječaci koje u većoj mjeri osjećaju dominaciju, antagonizam, natjecanje i svađe u odnosu sa sestrom. Ujedno se na poduzorku djevojčica značajnim prediktorom reaktivne agresivnosti istaknula i dimenzija topline u odnosu sa sestrom, odnosno djevojčice koje imaju lošiji odnos sa sestrom iskazuju višu reaktivnu agresivnost. Reaktivna agresivnost povezuje se s pojmom emocionalne agresije, odnosno impulzivne, provocirane agresije koja predstavlja odgovor na neke situacijske uvjete (npr. provokaciju ili frustraciju) i rezultat je emocionalnih promjena (npr. pojave srdžbe) do kojih dolazi u provocirajućoj situaciji (Keresteš, 2001.). Moguće je da su djevojčice osjetljivije na sukobe sa sestrom u smislu da u takvim situacijama češće reagiraju upravo emocionalnom agresijom.

Konflikti (svađe, blagi fizički obračuni) među braćom i sestrama dio su gotovo svake obiteljske svakodnevice. lako su normativna pojava unutar obitelji, učestali i prolongirani konflikti među braćom i sestrama mogu imati negativne implikacije na psihološku prilagodbu djece (Stocker, Burwell i Briggs, 2002.) te mogu biti rizičan faktor za razvoj antisocijalnog ponašanja. Uz konflikte, neka druga istraživanja (npr. Buist, 2010.) naglašavaju ulogu pozitivnih aspekata odnosa u objašnjenju psihološke prilagodbe adolescenta. $U$ ovom istraživanju, dimenzija topline izdvojila se kao važan faktor u objašnjenju agresivnosti, ali samo $u$ istorodnim dijadama što se može dovesti u vezu s činjenicom da se u prisnim interakcijama sa sestrama adolescentice uče obrazlagati mnoga svoja negativna iskustva što im omogućava kvalitetniju preradu tih iskustava kao i emocionalna rasterećenja s njima u vezi. Gold (1989.) je nadalje utvrdila da se više emocionalne potpore prima i pruža u odnosu sa sestrama nego li u odnosu s braćom, što može biti vrlo važno za razvoj pri-

\section{8 članci}


snosti kao i dobru prilagodbu pojedinca. $U$ ovom istraživanju navedene dimenzije kvalitete odnosa sa sestrom u većoj su mjeri objasnile varijancu dječjih problema eksternaliziranog tipa, preciznije reaktivne i proaktivne agresije, $u$ istorodnim dijadama. Odnosno, regresijskim analizama utvrđeno je da dimenzije kvalitete odnosa među braćom i sestrama na poduzorku djevojčica objašnjavaju $26 \%$ varijance reaktivne agresivnosti, odnosno $17 \%$ proaktivne agresivnost te skromnih $5 \%$ do $15 \%$ varijance mjera agresivnosti na poduzorku dječaka. Niže vrijednosti u objašnjenju eksternaliziranih problema kod dječaka mogu se dovesti u vezu s činjenicom da je u ovom istraživanju fokus bio samo na odnosu sa sestrom, a poznato je da je niža podudarnost ponašanja u mješovitim nego li u istorodnim dijadama (sestra imitira stariju sestru, brat brata). Odnosno, veća je vjerojatnost da će se dječaci identificirati sa svojom braćom u ovoj dobi. U prilog ovim pretpostavkama idu i nalazi istraživanja koji ukazuju da se najviše konflikata i agresivnog ponašanja u adolescentskoj dobi bilježi upravo među braćom (Williams, Conger i Blozis, 2007.). Nadalje, budući da dječaci općenito manifestiraju više problema eksternaliziranog tipa, pretpostavlja se da su adolescenti u ovoj dobi više pod utjecajem problematičnog ponašanja brata, a ne sestre.

Zaključno, dobiveni rezultati podržavaju postavke sistemsko-obiteljskog pristupa o složenim i dinamičnim odnosima među različitim podsustavima obitelji, u ovom radu roditeljskom podsustavu i podsustavu braće i sestara. Dobiveni rezultati ukazuju kako se neke dimenzije kvalitete odnosa među braćom i sestrama mogu smatrati rizičnim čimbenicima koji pridonose zastupljenosti dječjih problema i u skladu su s postojećim teorijskim pretpostavkama u ovom području; teorije socijalnog učenja (Bandura, 1977.), kao i teorije obiteljske prisile (Patterson, 1982.) prema kojima se temelji agresivnog ponašanja stvaraju kod kuće kroz osobno iskustvo ili opažanjem ponašanja drugih osoba, te indiciraju da su uz za razvoj agresivnog ponašanja uz roditelje bitni i drugi članovi obitelji, konkretnije, braća i sestre. Dosadašnja su istraživanja kod nas uglavnom naglašavala ulogu dimenzija roditeljskog ponašanja u objašnjenju agresivnog ponašanja. Budući da su ovim istraživanjem obuhvaćeni i drugi aspekti obiteljskih procesa koji se direktno povezuju s braćom i sestrama kao i mogućim doprinosima zajedničkih interakcija na razvojne ishode, rezultati dobiveni ovim istraživanjem predstavljaju svojevrsni teorijski i znanstveni doprinos objašnjenju agresije kod dječaka i djevojčica. Također, treba napomenuti da dimenzije kvalitete odnosa sa sestrom obuhvaćene ovim istraživanjem, objašnjavaju više varijance agresivnosti kod djevojčica nego li dječaka što zapravo indicira da su neki drugi faktori (osim interakcija sa sestrom i majkom) ključni za razvoj agresivnog ponašanja kod dječaka u razdoblju rane adolescencije (prvenstveno odnosi s ocem i bratom, sukobi između roditelja, interakcije s vršnjacima te biološki faktori). 
Na kraju, nužno je spomenuti i neka ograničenja ovog istraživanja. Prvo, bitno je reći da je ovo istraživanje provedeno na prigodnom uzorku učenika i kao takvo zasigurno $u$ određenoj mjeri ograničava mogućnost generalizacije dobivenih rezultata. Također treba istaknuti da su svi zaključci ovog istraživanja samo korelacijske prirode te da ne reflektiraju uzročno-posljedične odnose među analiziranim pojavama. Sljedeći metodološki nedostatak tiče se samog pristupa istraživanju odnosa među braćom i sestrama. $U$ ovom istraživanju prilikom procjene različitih aspekata percipirane kvalitete odnosa sa sestrom fokusirali smo se na pojedinca i njegovu percepciju odnosa sa sestrom, a ne na dijadnu analizu ovog odnosa koja bi bila poželjna budući da su podatci koji se prikupljaju u istraživanjima bliskih veza pa i odnosa između braće i sestara zapravo dijadne prirode. Znatan problem samoprocjena jest i pojava metodološke varijance koja može imati značajan utjecaj na opažene korelacije među mjerama različitih konstrukata. Nadalje, radi potrebe za kontrolom niza relevantnih varijabli, istraživanje je ograničeno na razmatranje odnosa sa sestrom, a od obiteljskih procesa na roditeljsko ponašanje majke, što onemogućuje generalizaciju spoznaja na odnose s braćom i roditeljsko ponašanje oca. Budući da je danas očinstvo zaseban predmet istraživanja, pa se i shvaća kao neovisan i različit oblik roditeljstva od majčinstva, bilo bi korisno uključiti u istraživanje i procjene oba roditelja te koristiti i druge metode za vrijeme prikupljanja podataka (posebno intervjue s djecom, majkom i ocem). Pritom bi bilo posebno interesantno proučavati i opažati interakcije i međusobni utjecaj braće i sestara (i roditelja) kroz duže vremensko razdoblje (dakle, longitudinalno). Na taj način mogli bi se u potpunosti razumjeti složeni procesi unutar obitelji koji pridonose uspješnijoj prilagodbi djece i kvaliteti odnosa među braćom i sestrama. Također, s obzirom na rodne razlike u načinima iskazivanja agresivnog ponašanja, kao i rodne razlike $u$ kvaliteti odnosa sa sestrom te s tim u svezi i veće podudarnosti ponašanja $\mathrm{u}$ istorodnim dijadama nego u mješovitim poželjno je i u daljnjim istraživanjima zasebno razmatrati kvalitetu odnosa s bratom, kod dječaka i djevojčica.

\section{ZAKLJUČAK}

lako su braća i sestre važan podsustav obiteljskog sustava i jedan od najtrajnijih odnosa u životu pojedinca, do prije nekoliko desetljeća njihova je uloga bila zanemarena kako u teorijskim razmatranjima obiteljskih odnosa tako, još više, i u empirijskim istraživanjima. Provedeno istraživanje, dakle, predstavlja svojevrstan doprinos boljem razumijevanju prirode odnosa koje mlađi adolescenti i adolescentice imaju sa svojom sestrom. $U$ ovom istraživanju dobiveno je kako dimenzije kvalitete odnosa sa sestrom imaju skroman, ali značajan doprinos u objašnjenju

\section{0 članci}


M. Jurkin, J. Ombla: Rodne razlike u percepciji odnosa sa sestrom i manifestaciji proaktivne...

agresivnog ponašanja kod dječaka, dok je doprinos objašnjenju agresivnog ponašanja kod djevojčica viši. Pri tome se najznačajnijom dimenzijom kvalitete odnosa sa sestrom u objašnjenju proaktivne i reaktivne agresivnosti pokazala dimenzija konflikata koja je doprinijela objašnjenju reaktivne i proaktivne agresivnosti djevojčica kod dječaka i djevojčica. Na temelju dobivenih rezultata može se zaključiti da ulogu sestre ne treba zanemariti u ranoj adolescenciji. Dječja percepcija kvalitete ovog odnosa objašnjava pojedine aspekte psihosocijalnog funkcioniranja što otvara prostor za praktične intervencije kojima će se roditelje usmjeravati na ponašanja i aktivnosti koji će unaprijediti odnos među braćom i sestrama, ali i doprinijeti uspješnijoj prilagodbi djece u adolescentskoj dobi. Također, djecu se može poučavati efikasnim strategijama vlastite emocionalne regulacije koja će imati pozitivan učinak na njihova emocionalna iskustva s roditeljima i braćom i sestrama.

\section{LITERATURA}

1. Aguilar, B., O'Brien, K. M., August, G. J., Aoun, S. L. \& Hektner, J. M. (2001). Relationship quality of aggressive children and their siblings: A multi-informant, multi-measure investigation. Journal of Abnormal Child Psychology, 29, 479-489.

2. Archer, J. (2004). Sex differences in aggression in real-world settings: A metaanalytic review. Review of General Psychology, 8, 291-322.

3. Bandura, A. (1977). Social learning theory. New York: General Learning Press.

4. Bedford, V. H. \& Volling, B. (2004). A dynamic ecological systems perspective on emotion regulation development within the sibling relationship context. In: Lang, F. \& Fingerman, K. (eds.), Growing together: Personal relationships across the lifespan. New York: Cambridge University Press, 76-101.

5. Brody, G. H. (1998). Sibling relationship quality: Its causes and consequences. Annual Review, 49, 1-24.

6. Buhrmester, D. (1992). The developmental courses of sibling and peer relationships. In: Boer, F. \& Dunn, J. (eds.), Children's sibling relationship: Developmental and clinical issues. Hillsdale, NJ: Erlbaum, 19-40.

7. Buhrmester, D. \& Furman, W. (1990). Perceptions of sibling relationships during middle childhood and adolescence. Child Development, 61 (5), 1387-1398.

8. Buist, K. L. (2010). Sibling relationship quality amd adolescent deliquency: A latent growth curve approach. Journal of Family Psychology, 24, 400-410.

9. Bun Lam, C., Solmeyer, A. R. \& McHale, S. M. (2012). Sibling relationship and empathy across the transition to adolescence. Journal of Youth and Adolescence, 41 (12), 1657-1670. 
10. Cicirelli, V. G. (1991). Sibling relationships across the life span. New York: Plenum Press.

11. Cole, D. A., Tram, J. M., Martin, J. M., Homan, K. B., Ruiz, M. D. \& Jacquez, F. M. (2002). Individual differences in the emergence of depressive symptoms in children and adolescents: A longitudinal investigation of parent and child reports. Journal of Abnormal Psychology, 111 (1), 156-165.

12. Ćubela Adorić, V. (2006). Prisni odnosi u odrasloj i starijoj dobi, U: KackovićGrgin, K. \& Ćubela Adorić, V. (ur.), Odabrane teme iz psihologije odraslih. Jastrebarsko: Naklada Slap, 161-215.

13. Dunn, J. (2000). State of the art: Siblings. The Psychologist, 13, 244-248.

14. Dunn, J. \& Munn, P. (1986). Sibling quarrels and maternal intervention: Individual differences in understanding and agression. Journal of Child Psychology and Psychiatry, 27, 583-595.

15. Feinberg, M. E., McHale, S. M., Crouter, A. C. \& Cumsille, P. (2003). Sibling differentiation: Sibling in parent relationship trajectories in adolescence. Child Development, 74 (5), 1261-1274.

16. Felson, R. B. \& Russo, N. J. (1988). Parental punishment and sibling aggression. Social Psychology Quarterly, 51, 11-18.

17. Furman, W. \& Buhrmester, D. (1985). Children's perceptions of the qualities of sibling relationships. Child Development, 56, 448-461.

18. Finzi Dottan, R. \& Cohen, O. (2011). Young adult sibling relations: The effects of perceived parental favoritism and narcissism. The Journal of Psychology, $145(1), 1-22$.

19. Gass, K., Jenkins, J. \& Dunn, J. (2007). Are sibling relationship protective? A longitudinal study. Journal of Child Psychology and Psychiatry, 48 (2), 165-175.

20. Gold, D. T. (1989). Sibling relationships in old age: A typology. International Journal of Aging and Human Development, 28 (1), 37-51.

21. Howe, N., Karos, L. K. \& Aquan-Assee, J. (2011). Sibling relationship quality in early adolescence: Child and maternal perceptions and daily interactions. Infant and Child Development, 20, 227-245.

22. Kim, J. Y., McHale, S. M., Osgood, D. W. \& Crouter, A. C. (2006). Longitudinal course of family correlates of sibling relationships from childhood through adolescence. Child Development, 77 (6), 1746 -1761.

23. Keresteš, G. (1999). Agresivno i prosocijalno ponašanje školske djece u kontekstu ratnih zbivanja: Provjera posredujućeg utjecaja roditeljskog ponašanja. Doktorska disertacija. Zagreb: Filozofski fakultet Sveučilišta u Zagrebu.

24. Keresteš, G. (2001). Roditeljsko ponašanje i obiteljska klima u obiteljima samohranih majki. Društvena istraživanja, 10 (4/5), 903-925. 
M. Jurkin, J. Ombla: Rodne razlike u percepciji odnosa sa sestrom i manifestaciji proaktivne...

25. Keresteš, G. (2002). Dječje agresivno i prosocijalno ponašanje u kontekstu rata. Jastrebarsko: Naklada Slap.

26. Kramer, L., Perozynski, L. A. \& Chung, T. (1999). Parental responses to sibling conflict:The effects of development and parent gender. Child Development, 70, 1401-1414.

27. Kramer, L. \& Kowal, A. (2005). Sibling relationship quality from birth to adolescence: The enduring contributions of friends. Journal of Family Psychology, 19 (4), 503-511.

28. Lacković Grgin, K. (2006). Psihologija adolescencije. Jastrebarsko: Naklada Slap.

29. McHale, S. M., Updegraff, K. A. \& Whiteman, S. D. (2012). Sibling relationship and influences in childhood and adolescence. Journal of Marriage and Family, 74, 913-930.

30. Noller, P. (2005). Sibling relationship in adolescence: Learning and growing together. Personal Relationships, 12, 1-22.

31. Ostrov, J. M., Crick, N. R. \& Stauffacher, K. (2006). Relational aggression in sibling and peer relationships during early childhood. Applied Developmental Psychology, 27, 241-253.

32. Patterson, G. R. (1982). Coercive family process. Eugene, OR: Castalia.

33. Richmond, M. K., Stocker, C. M. \& Rienks, S. L. (2005). Longitudinal association between sibling relationship quality, parental differential treatment, and children's adjustment. Psychology Journal of Family, 19, 550-559.

34. Scharf, M., Shulman, S. \& Avigad Spitz, L. (2007). Sibling relationship in emerging adulthood and in adolescence. Journal of Adolescent Research, 20, 64-90.

35. Stocker, C. M. (1993). Siblings adjustment in middle childhood: Links with mother-child relationships. Journal of Applied Developmental Psychology, 14, 485-499.

36. Stocker, C. M. (1994). Children's perceptions of relationships with sibling, friends and mothers: Compensatory processes and links with adjustment. Journal of Child Psychology and Psychiatry, 35, 1447-1459.

37. Stocker, C. M., Burwell, R. A. \& Briggs, M. L. (2002). Sibling conflict in midlle childhood predicts children's adjustment in early adolescence. Journal of Family Psychology, 16, 50-57.

38. Stormshak, E. A., Bellanti, C. J. \& Bierman, K. L. (1996). The quality of sibling relationships and the development of social competence and behavioral control in agressive children. Developmental Psychology, 32 (1), 79-89.

39. Updegraff, K. A., Thayer, S. M., Whiteman, S. D., Denning, D. J. \& McHale, S. M. (2005). Relational aggression in adolescents' sibling relationships: Links to sibling and parent-adolescent relationship quality. Family Relations: Interdisciplinary Journal of Applied Family Studies, 54, 373-385. 
40. Volling, B., McElwain, N. L. \& Miller, A. L. (2002). Emotion regulation in context: The jealousy complex between siblings and its relation with child and family characteristics. Child Development, 73, 581-600.

41. Williams, S. T., Conger, K. J., Blozis, S. A. (2007). The development of interpersonal aggression during adolescence. The importance of parents, siblings, and family economics. Child Development, 78, 1526-1542.

42. Zahn-Waxler, C., Klimes-Dougan, B. \& Slattery, M. J. (2000). Internalizing problems of childhood and adolescence: Prospects, pitfalls and progress in understanding the development of anxiety and depression. Development and Psychopathology, 12, 443-466.

\author{
Marina Jurkin \\ Jelena Ombla \\ University of Zadar \\ Department of Psychology
}

\title{
GENDER DIFFERENCES IN THE PERCEPTION OF RELATIONSHIPS WITH SISTERS AND THE MANIFESTATION OF PROACTIVE AND REACTIVE AGRESSION IN YOUNG ADOLESCENTS
}

\begin{abstract}
The main goal of this research was to examine the role that the quality of relationships among siblings has in explaining aggressive behaviour during adolescence. In other words, the research studied the contribution of specific quality dimensions (warmth, conflicts and mother's favouritism) of relationships with sisters in explaining proactive and reactive aggression in young adolescents. Boys $(N=160)$ and girls $(N=192)$ aged 13 to 15 who have an up to 5 years younger or older sister participated in the research. The results of the analyses of gender differences show that boys have a greater tendency to exhibit proactive and reactive aggression, and that in comparison with boys, girls perceive significantly more warmth in their relationships with their sisters. The correlation and regression analyses confirm the assumptions that there is a strong connection between positive and negative aspects of relationships with sisters on the one hand and some aspects of psychosocial functioning in mixed (brother-sister) and same-gender dyads (sister-sister) on the other. More specifically, the conflict dimension in relationships with sisters is a significant independent predictor of reactive and proactive aggression in both boys and girls. Namely, the results of regression analyses show a higher level of proactive and reactive aggression in girls and boys who have stronger feelings of antagonism, competitiveness, arguing and domination in relationships with their sisters. In the girls subsample, another significant predictor of reactive aggression was the dimension of warmth in the relationships with their sisters.
\end{abstract}

Key words: quality of relationships with sisters, proactive and reactive aggression, young adolescents.

\section{4 članci}

